\title{
Viability, infectivity and fatty acid synthetic activity of Perkinsus marinus meront cells incubated in estuarine and artificial seawater
}

\author{
Fu-Lin E. Chu*, Eric D. Lund \\ Virginia Institute of Marine Science, College of William and Mary, 1208 Greate Road, Gloucester Point, Virginia 23062, USA
}

\begin{abstract}
We investigated the viability and fatty acid synthetic activity of in vitro cultured Perkinsus marinus (Dermo) in lipid-free medium and estuarine water, and the infectivity of $P$. marinus maintained in artificial seawater (ASW). Viability and fatty acid synthetic activity in $7 \mathrm{~d}$ old $P$. marinus meronts maintained in lipid-free medium and estuarine water were tested. The infectivity of meronts incubated in ASW was examined by first incubating $P$. marinus meronts in ASW for 2, 3 or $7 \mathrm{~d}$, and then inoculating viable ASW-incubated meronts into the shell cavity of individual oysters Crassostrea virginica. $P$. marinus infection prevalence and intensity in oysters were determined 9 wk post-inoculation. Heavy mortality occurred in meronts maintained in estuarine water, a drop from an initial value of $100 \%$ viable to 7.8 and $6.1 \%$ after 3 and $14 \mathrm{~d}$ incubation, respectively. Viability was 85 and $67 \%$ in meronts maintained in lipid-free medium for 3 and $24 \mathrm{~d}$, respectively. Meronts kept in lipid-free medium for $14 \mathrm{~d}$ retained their ability to synthesize fatty acids. Viable meronts incubated in ASW remained infective for up to $7 \mathrm{~d}$. The infection prevalences were 85, 48 and 100\%, in the treatments inoculated with viable meronts that were incubated in ASW for 2, 3 and 7 d, respectively. Infection prevalence in the group inoculated with viable meronts immediately after they were transferred to ASW ranged from 61 to $85 \%$. Our results suggest that in nature meronts can survive for at least $14 \mathrm{~d}$ outside the host. Viable meronts are not only infective, but are also able to replicate and retain their fatty acid synthetic ability for $7 \mathrm{~d}$.
\end{abstract}

KEY WORDS: Perkinsus marinus $\cdot$ Viability $\cdot$ Infectivity $\cdot$ Fatty acid synthesis

Resale or republication not permitted without written consent of the publisher

\section{INTRODUCTION}

Perkinsus marinus (Dermo) is the parasite of a sessile host, the eastern oyster Crassostrea virginica. This parasite has continuously caused severe loss of eastern oyster populations on the US East and Gulf Coasts since the 1950s, and 4 life stages-meront (trophozoite), prezoosporangia (hypnospores), zoosporangia, and biflagellated zoospores - have been identified and described (Perkins 1966, 1988). The meront stage comprises the majority of the parasite load in tissues of heavily infected oysters. When tissue-associated meronts are placed in fluid thioglycollate medium (FTM) for 4 to $5 \mathrm{~d}$, they develop into prezoosporangia. Zoosporulation (production of biflagellated zoospores) usually occurs after incubating FTM-cultured pre- zoosporangia in estuarine or seawater (a salinity of 20 to 22) for 5 to $6 \mathrm{~d}$. Prezoosporangia are sometimes found in tissues of infected oysters. However, it is unclear whether prezoosporangia released from moribund and deceased oysters are able to zoosporulate in nature. The meront stage is believed to be the primary agent for disease transmission (Perkins 1988, Chu 1996). Although exactly how $P$. marinus infective cells (e.g. meronts) enter a new host is not well understood, the disease caused by $P$. marinus is transmitted via dispersal of infective cells into the water column from live and moribund/dead infected oysters (e.g., Chu 1996, Bushek et al. 2002, Chu et al. 2002, Ragone Calvo et al. 2003).

In previous studies, we revealed that, unlike other parasitic protozoans, Perkinsus marinus has a unique 
fatty acid synthetic capability (Soudant \& Chu 2001, Chu et al. 2002, 2004). The meront stage of this parasite differs from all other parasitic protozoans that rely on their host for essential lipids. P. marinus meronts can synthesize a range of saturated and unsaturated fatty acids, including the essential fatty acid, arachidonic acid (AA) (Soudant \& Chu 2001, Chu et al. 2002). The ability of $P$. marinus to synthesize AA is novel. No other parasitic protozoan has been reported to have such a capability. This capability may be related to the disease transmission processes, since lipids are essential membrane components and comprise energy reserves for growth and development and at times of no or limited nutrient supply.

It has long been hypothesized that Perkinsus marinus infective cells can survive in nature for a considerable length of time and remain infective when they enter a new host. However, no study has been conducted to examine the viability and infectivity of water-borne $P$. marinus infective cells, how long the primary transmission stage meront remains viable in the water column, and whether or not the 'viable' meronts are infective. No intermediary host is known to act as a vector for disease transmission by this parasite. Although Dermo disease could be transmitted via scavengers (Andrew \& Hewatt 1957, Hoese 1963), and the snail Boonea impressa could be a potential vector for Dermo transmission (White et al. 1987), there is accumulated evidence supporting transmission through water-borne infective particles as the primary mechanism (e.g. Chu \& Volety 1997, Bushek et al. 2002, Ragone Calvo et al. 2003). As such, the length of time that $P$. marinus cells disassociated from the host can remain viable and infective in the water column is critical for disease transmission and has a direct effect on their ability to infect distant host populations. The objectives of the present study were (1) to investigate the length of time that the parasite remains infective and viable in estuarine water and in a lipid-free environment, and (2) to determine, by incubating meront cells in estuarine water, if the meront stage of $P$. marinus retains its fatty acid synthetic ability and can proliferate outside the host in the wild.

\section{MATERIALS AND METHODS}

Meront cell culture. Perkinsus marinus meront cells were cultivated as previously described (Chu et al. 2002) in the medium defined by La Peyre et al. (1993). Medium was prepared with artificial seawater (ASW) and adjusted to an osmolarity of 590 (equivalent to a salinity of 20, Lund et al. 2004). The medium was then sterilized by $0.22 \mu \mathrm{m}$ filtration and stored at $4^{\circ} \mathrm{C}$ until use. Meronts were inoculated at a concentration of $1 \times 10^{6} \mathrm{ml}^{-1}$ and cultured in $10 \mathrm{ml}$ aliquots of medium in T-10 tissue culture flasks at $28^{\circ} \mathrm{C}$. Meronts at exponential growth phase $(7 \mathrm{~d}$ old) were harvested and used for all experiments.

Oysters. To avoid potential confounding effects due to the presence of the parasite, adult oysters Crassostrea virginica were obtained from Pemaquid Oyster Company, Waldoboro, Maine, where oysters are rarely infected by Perkinsus marinus (Ford 1996). Oysters were maintained in a closed seawater system at ambient temperature $\left(20^{\circ} \mathrm{C}\right)$ and salinity $(15$ to 20$)$ in $2 \mu \mathrm{m}$-filtered York River water. Upon arrival, 15 oysters were tested for $P$. marinus infection using total body burden assessment (Choi et al. 1989, Bushek et al. 1994b). No infection was detected in any of the sampled oysters. Oysters were fed an algal paste (Instant Algae Shellfish diet 1800, Reed Mariculture) at a ration of $0.2 \mathrm{~g}$ oyster $^{-1} \mathrm{day}^{-1}$ and allowed to acclimate for $12 \mathrm{~d}$ prior to experimental use.

Lipid and fatty acid analyses. Total lipids were extracted from meronts and oyster tissues according to the procedure described by Bligh \& Dyer (1959). Fatty acid composition and contents of meronts and oyster tissues were analyzed using gas chromatograph/flame ionization detector (GC/FID). Briefly, total lipids were transesterified according to Metcalfe \& Schmitz (1961) and fatty acid methyl esters (FAMEs) extracted with carbon disulfide (Marty et al. 1992). The organic phase was evaporated, redissolved in hexane, and analyzed by a GC (Varian 3300; Varian Analytical Instruments) equipped with a flame ionization detector, using a DBWAX capillary column $(25 \mathrm{~m} \times 0.32 \mathrm{~mm} ; 0.2 \mu \mathrm{m}$ film thickness; J\&W Scientific). Identification of FAMEs was based on the comparison of their retention times with those of authentic standards and confirmed by gas chromatograph-mass spectrometry (GC/MS). The quantity of each component was calculated based on the internal standard.

Neutral red assay. Neutral red (NR) assay (La Peyre \& Chu 1994) was used to assess the viability of Perkinsus marinus meront cells. The NR assay examines uptake of liquid droplets or fluid-phase endocytosis by living cells; thus it is an assessment of cell viability. Briefly, meront cells were incubated with NR solution (Sigma N2889) in 1:9 ratio for $30 \mathrm{~min}$ and the number of viable cells (stained) and dead (non-stained) cells were counted using a Bright-Line hemocytometer (Reichert).

Diagnosis of Perkinsus marinus infection. Prevalence and intensity of Perkinsus marinus infection in experimental oysters were determined using total body burden assessment (Choi et al. 1989, Bushek et al. 1994b). Tissues from individual oysters were removed. The total wet weight of oyster tissue and dry shell weight were recorded, and whole oyster tissues 
were homogenized in $0.22 \mu \mathrm{m}$-filtered York River water (the maintenance water). Tissue homogenates were added to FTM containing antibiotics (penicillin/streptomycin), incubated in the dark at room temperature for 5 to $7 \mathrm{~d}$. This medium stimulates $P$. marinus meront cells to develop into prezoosporangia, which are larger and easier to identify than meronts. Subsequent treatment with sodium hydroxide digests the oyster tissue, but not the prozoosporangia, which can be stained with Lugol's solution and counted. Triplicate tissue suspensions of each oyster were assayed for body burden. Results were expressed as cell number $\mathrm{g}^{-1}$ wet tissue weight (mean $\pm \mathrm{SD}$ ).

Expts 1A and 1B. Viability, proliferation and fatty acid synthetic activity of meronts maintained in estuarine water and lipid-free medium. We conducted 2 experiments to determine the length of time that Perkinsus marinus meronts remain viable in estuarine water and lipid-free medium, and if meronts proliferate in lipid-free medium and estuarine water.

Expt 1A: To test how long meronts remain viable and whether they replicate in estuarine water and lipidfree environment, $7 \mathrm{~d}$ old meronts were inoculated in regular medium, lipid-free medium (medium without added lipid concentrate), or $0.22 \mu \mathrm{m}$-filtered estuarine water (York River water, YRW) adjusted to a salinity similar to that of the regular medium (salinity $=20 ; n=$ 3 ). Their viability and proliferation were monitored for $24 \mathrm{~d}$ at $28^{\circ} \mathrm{C}$. Samples were taken at 3, 7, 14 and $24 \mathrm{~d}$ post-inoculation to count cell number and test viability, using a NR assay.

Expt 1B: This experiment repeated Expt 1A, with similar experimental conditions, with the exception that the meronts were incubated for a different time (14 d). Also, in addition to taking samples for measurements of viability of meronts at 3, 7 and $14 \mathrm{~d}$ post-inoculation, meronts were also sampled at the beginning and 3,7 and $14 \mathrm{~d}$ post-inoculation and stored at $-80^{\circ} \mathrm{C}$ for later lipid and fatty acid analyses. In this experiment, only viable meronts were counted, but all meronts were collected for lipid and fatty acid analysis.

Expts 2A and 2B. Infectivity of Perkinsus marinus meronts maintained in host-free environment. We conducted 2 separate experiments to test the infectivity of 3 different Perkinsus marinus cultures incubated in artificial seawater (ASW).

Expt 2A: After incubation in ASW for 0, 2 or $7 \mathrm{~d}$, Perkinsus marinus cell viability was assessed using an NR assay prior to use for artificial infection. A concentration of $1.5 \times 10^{6}$ viable 0,2 and $7 \mathrm{~d}$ ASW-incubated $P$. marinus cells was injected into the shell cavity of oysters ( $\mathrm{n}=21$ oysters for each incubation period). Negative controls were inoculated with filtered ASW only. Artificially infected oysters were maintained individually in $2 \mathrm{l}$ jars for $9 \mathrm{wk}$ at 20 to $25^{\circ} \mathrm{C}$. Oysters were fed an algal paste (Instant Algae Shellfish Diet 1800, Reed Mariculture) at a daily ration of $0.2 \mathrm{~g} \mathrm{oyster}^{-1}$, and water was changed 3 times per week. At the end of the experiment ( $9 \mathrm{wk}$ after $P$. marinus meront cell inoculation into the shell cavity), $P$. marinus infectivity was determined using a body burden assay (Choi et al. 1989, Bushek et al. 1994b).

Expt 2B: The experimental conditions were similar to those described for Expt 2A, except that different concentrations of viable Perkinsus marinus cells were used for infection and they were incubated in ASW for different lengths of time. In this experiment, $P$. marinus meront cells were incubated in ASW for 0,3 or $7 \mathrm{~d}$ prior to use for infection. A concentration of $4.0 \times 10^{6}$ of viable 0,3 and $7 \mathrm{~d}$ ASW-incubated cells was injected into the shell cavity of oysters $(n=21$ oysters per incubation period). As for Expt 2A, negative controls were inoculated with filtered ASW only. We diagnosed the oysters for prevalence and intensity of $P$. marinus infection 9 wk after artificial infection.

Statistical analysis. Weight percent and $\mathrm{mg} \mathrm{ml}^{-1} \mathrm{DW}$ (dry weight) fatty acid compositions from Expt 1B were analyzed by 2 -way analysis of variance (ANOVA) (independent factors of time and medium type). Data on prevalence of infection from Expt 2 were analyzed by chi square. When chi square results were significant $(\mathrm{p}<0.05)$, treatments were compared by orthagonal contrasts. All percentage data were arcsine transformed prior to analysis.

\section{RESULTS}

Expts $1 \mathrm{~A}$ and $1 \mathrm{~B}$ examined the proliferation and the length of time that Perkinsus marinus meront cells remain viable in lipid-free medium and estuarine water, Expts 2A and 2B their infectivity in a host-free environment.

\section{Expt 1A. Proliferation and viability of meronts}

Meronts proliferated in both regular and lipid-free media during the course of the experiment (Fig. 1). Cell number in the regular medium increased from a Day 0 density of $6.5 \times 10^{6}$ cells $\mathrm{ml}^{-1}$ to a peak of $30.5 \times$ $10^{6}$ cells ml $\mathrm{m}^{-1}$ at Day 14 , with a density of $28.3 \times 10^{6}$ cells $\mathrm{ml}^{-1}$ on Day 24. Cell number in the lipid-free medium increased from a Day 0 density of $7.5 \times 10^{6}$ cells $\mathrm{ml}^{-1}$ to a peak of $13.3 \times 10^{6}$ cells ml $^{-1}$ at Day 14 , with a density of $9.2 \times 10^{6}$ cells ml ${ }^{-1}$ on Day 24 (Fig. 1). Mortality in meronts maintained in lipid-free medium was much lower than for those maintained in estuarine water, but higher than for those maintained in regular medium. Viability at $24 \mathrm{~d}$ was 80 and $67 \%$ in meronts 
maintained in regular medium and lipid-free medium, respectively (Fig. 2). The meront cells maintained in estuarine water (York River water, YRW) declined from an initial density of $7.4 \times 10^{6}$ to $6.63 \times 10^{5} \mathrm{cells} \mathrm{ml}^{-1}$ by Day 3 and continued to decrease to $5.4 \times 10^{5}$ cells ml $^{-1}$ by Day 14 (Fig. 1). The cell viability for this treatment dropped from an initial value of nearly 100 to $7.8 \%$ at Day 3 and $6.1 \%$ at Day 14 (Fig. 2).

\section{Expt 1B. Proliferation and fatty acid content composition of meronts}

\section{Proliferation}

Although only viable cells were counted in Expt 1B, results were consistent with those of Expt 1A (Fig. 3). Meronts cultivated in regular medium continued to proliferate over the course of the experiment, increasing from an initial concentration of $1.3 \times$ $10^{6}$ to $43.5 \times 10^{6}$ cells ml $^{-1}$ at Day 14 (Fig. 3). Meront cell number in the lipid-free medium treatment increased from an initial concentration of $1.5 \times 10^{6}$ to

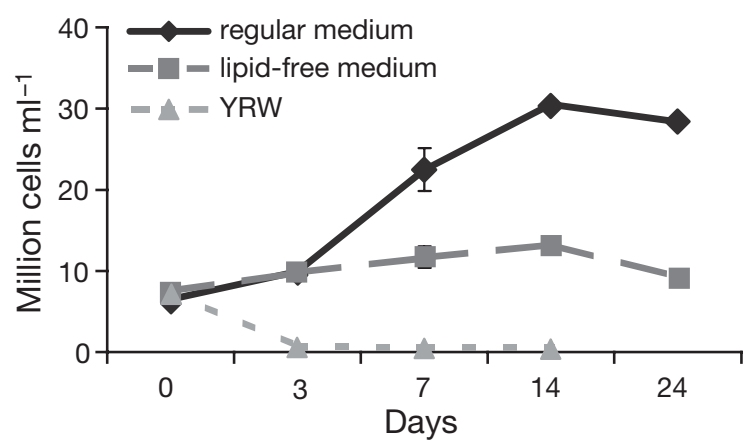

Fig. 1. Perkinsus marinus. Growth (cell numbers, mean $\pm \mathrm{SD}$, $\mathrm{n}=3$; Expt 1A) of meronts maintained in regular medium, lipid-free medium and $0.22 \mu \mathrm{m}$-filtered estuarine water (York River water, YRW)

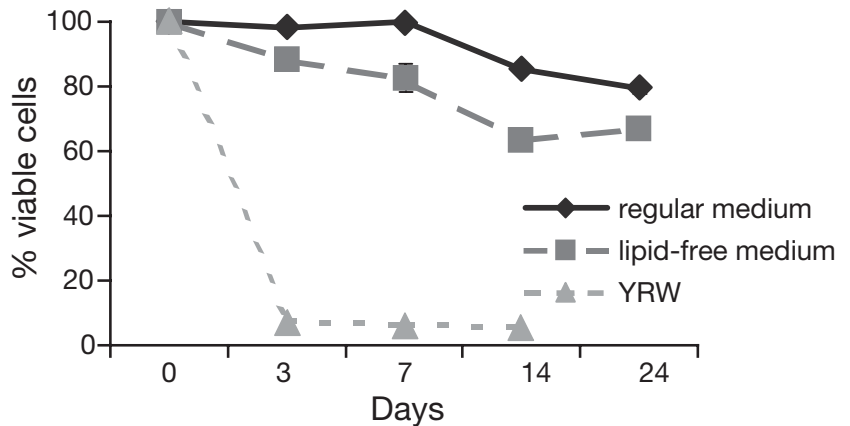

Fig. 2. Perkinsus marinus. (mean $\pm \mathrm{SD}, \mathrm{n}=3$; Expt 1A). Viability of meronts maintained in regular medium, lipid-free medium and $0.22 \mu \mathrm{m}$-filtered YRW, measured by neutral red viability assay
$24.1 \times 10^{6}$ cells $\mathrm{ml}^{-1}$ at Day 3, then declined to $14 \times$ $10^{6}$ cells $\mathrm{ml}^{-1}$ by Day 14 (Fig. 3). Meront number declined in estuarine YRW from an initial concentration of $1.5 \times 10^{6}$ to $0.64 \times 10^{6}$ cells ml ${ }^{-1}$ by Day 3 , but declined only slightly thereafter. At Day 14 , there were still $0.5 \times 10^{6}$ viable cells $\mathrm{ml}^{-1}$ in the YRW treatment (Fig. 3).

Total fatty acid content in cultures

Meronts in both lipid-free medium and regular medium increased in total fatty acid content $\mathrm{g}^{-1} \mathrm{DW}$ of meronts over the duration of the experiment, while the meronts maintained in $0.22 \mu \mathrm{m}$-filtered estuarine YRW declined from initial values (Fig. 4). The fatty acid content of the positive control increased at every sampling point from an initial concentration of 11.9 to $28.8 \pm 2.4 \mathrm{mg} \mathrm{g}^{-1} \mathrm{DW}$ (mean $\pm \mathrm{SD}$ ) at Day 14. The lipid-free medium treatment increased from an initial value of 11.9 to $22.0 \pm 4.7 \mathrm{mg} \mathrm{g}^{-1}$ DW by Day 7 , then remained relatively static $\left(20.5 \pm 2.1 \mathrm{mg} \mathrm{g}^{-1} \mathrm{DW}\right)$ until Day 14. The total fatty acid content in the YRW

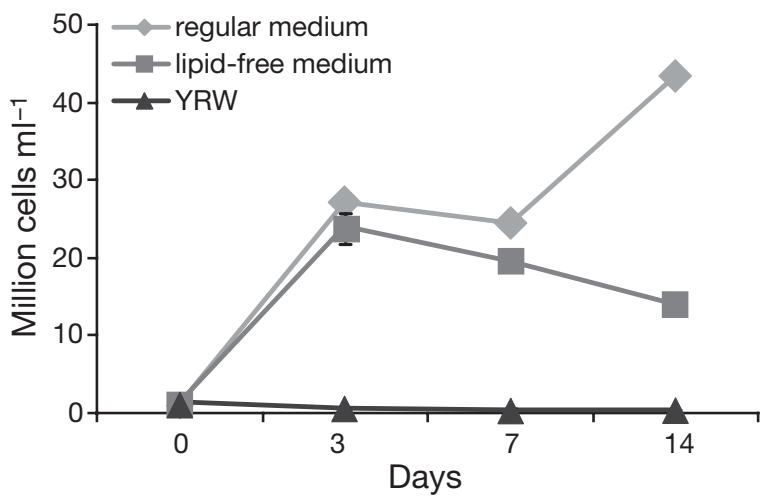

Fig. 3. Perkinsus marinus. Meront cell number (mean $\pm \mathrm{SD}$, $\mathrm{n}=3$; Expt 1B) cultivated in regular medium, lipid-free medium and YRW

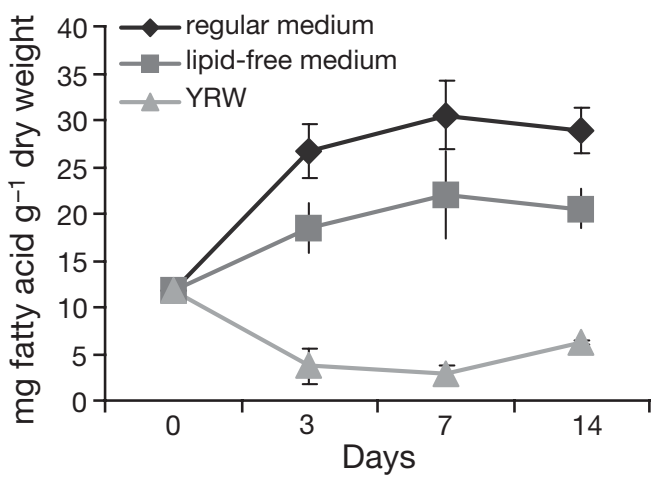

Fig. 4. Perkinsus marinus. Total fatty acid content (mean $\pm \mathrm{SD}$, $\mathrm{n}=3$; Expt 1B) of meronts in regular medium, lipid-free medium and YRW 
Table 1. Perkinsus marinus. Weight percent (mean $\pm \mathrm{SD}, \mathrm{n}=3$ ) of major fatty acids in meronts maintained in regular medium, lipid-free medium and filtered York River water for $14 \mathrm{~d}$ (Expt 1B). Only major fatty acid components are shown (i.e. $>2 \%$ ). FAME: fatty acid methyl ester; RM: regular medium; LF: lipid-free medium; YRW: $0.2 \mu \mathrm{m}$-filtered York River water. ${ }^{\mathrm{a}}$ : Significantly different for 'treatment' $(p<0.05){ }^{b}$ : significantly different for 'day' $(p<0.05)$; nd: non detectable

\begin{tabular}{|c|c|c|c|c|c|c|c|c|c|c|}
\hline \multirow{2}{*}{ FAME } & \multirow{2}{*}{$\begin{array}{c}\text { Day } 0 \\
\text { (initial) }\end{array}$} & \multicolumn{3}{|c|}{ Day 3} & \multicolumn{3}{|c|}{ Day 7} & \multirow{2}{*}{\multicolumn{2}{|c|}{ - Day 14}} & \multirow[b]{2}{*}{ YRW } \\
\hline & & $\mathrm{RM}$ & LF & YRW & $\mathrm{RM}$ & $\mathrm{LF}$ & YRW & & & \\
\hline $14: 0^{\mathrm{ab}}$ & 6.5 & $5.7 \pm 0.1$ & $4.4 \pm 0.1$ & $7.8 \pm 0.5$ & $4.4 \pm 02$ & $2.9 \pm 0.1$ & $8.2 \pm 0.4$ & $3.7 \pm 0.1$ & $2.0 \pm 0.1$ & $5.1 \pm 1.3$ \\
\hline $16: 0^{\mathrm{ab}}$ & 11.0 & $13.3 \pm 0.1$ & $11.9 \pm 0.2$ & $14.1 \pm 0.3$ & $11.3 \pm 0.2$ & $9.1 \pm 0.1$ & $13.7 \pm 0.3$ & $11.5 \pm 0.1$ & $9.1 \pm 0.4$ & $12.9 \pm 1.2$ \\
\hline $16: 1(n-7)^{a b}$ & 3.3 & $2.1 \pm 0.0$ & $1.0 \pm 0.0$ & $3.6 \pm 0.1$ & $1.3 \pm 0.0$ & $0.8 \pm 0.0$ & $3.8 \pm 0.1$ & $1.2 \pm 0.0$ & $0.7 \pm 0.0$ & $3.3 \pm 0.0$ \\
\hline $18: 0^{\mathrm{ab}}$ & 6.5 & $6.8 \pm 0.3$ & $6.9 \pm 0.1$ & $6.2 \pm 0.1$ & $7.7 \pm 0.1$ & $5.0 \pm 0.1$ & $5.5 \pm 0.1$ & $6.2 \pm 0.1$ & $3.6 \pm 0.0$ & $5.3 \pm 1.0$ \\
\hline $18: 1(n-9)^{a b}$ & 33.5 & $22.8 \pm 0.2$ & $24.3 \pm 0.3$ & $34.1 \pm 0.8$ & $28.2 \pm 0.5$ & $31.9 \pm 0.1$ & $35.2 \pm 0.2$ & $31.6 \pm 0.3$ & $34.5 \pm 0.8$ & $34.8 \pm 2.5$ \\
\hline $18: 1(n-7)^{a b}$ & 4.7 & $2.8 \pm 0.0$ & $1.6 \pm 0.0$ & $4.4 \pm 0.0$ & $2.1 \pm 0.0$ & $1.2 \pm 0.0$ & $4.4 \pm 0.1$ & $1.9 \pm 0.0$ & $1.1 \pm 0.0$ & $4.5 \pm 0.2$ \\
\hline $18: 2(n-6)^{a b}$ & 2.7 & $4.1 \pm 0.1$ & $4.9 \pm 0.1$ & $3.3 \pm 0.1$ & $2.9 \pm 0.0$ & $3.9 \pm 0.0$ & $3.5 \pm 0.0$ & $3.0 \pm 0.1$ & $4.2 \pm 0.1$ & $3.4 \pm 0.2$ \\
\hline $20: 1(n-9)^{a b}$ & 9.5 & $5.6 \pm 0.0$ & $6.0 \pm 0.1$ & $7.4 \pm 0.2$ & $7.3 \pm 0.2$ & $7.5 \pm 0.1$ & $6.9 \pm 0.1$ & $6.1 \pm 0.2$ & $5.5 \pm 0.3$ & $7.1 \pm 0.6$ \\
\hline $20: 4(n-6)^{a b}$ & 6.5 & $16.8 \pm 0.6$ & $21.5 \pm 0.7$ & $6.1 \pm 0.3$ & $14.1 \pm 0.1$ & $19.7 \pm 0.0$ & $6.2 \pm 0.2$ & $15.0 \pm 0.2$ & $22.1 \pm 0.1$ & $7.0 \pm 0.3$ \\
\hline $20: 5(n-3)^{a}$ & 3.2 & $2.8 \pm 0.1$ & $0.9 \pm 0.1$ & $2.8 \pm 0.1$ & $2.4 \pm 0.0$ & $0.8 \pm 0.0$ & $3.1 \pm 0.1$ & $2.6 \pm 0.0$ & $0.9 \pm 0.0$ & $3.4 \pm 0.2$ \\
\hline $22: 1(n-9)^{a}$ & 2.0 & $0.7 \pm 0.1$ & nd & nd & $0.8 \pm 0.1$ & nd & nd & $0.5 \pm 0.0$ & nd & $1.2 \pm 0.2$ \\
\hline $24: 0^{\mathrm{a}}$ & 2.5 & $5.1 \pm 0.2$ & $5.9 \pm 0.3$ & $2.5 \pm 0.5$ & $5.0 \pm 0.3$ & $61 . \pm 0.1$ & $3.1 \pm 0.1$ & $5.0 \pm 0.1$ & $6.2 \pm 0.5$ & $3.1 \pm 0.1$ \\
\hline
\end{tabular}

treatment had declined over 3-fold by Day 7, but interestingly, the total fatty acid content had increased to $6.0 \mathrm{mg} \mathrm{g}^{-1} \mathrm{DW}$ by Day 14 .

\section{Weight percent fatty acid composition in cultures}

The weight percentage of all major fatty acids differed significantly $(\mathrm{p}<0.05)$ with treatment, but 20:5 (n-3), 22:1(n-9) and 24:0 did not vary significantly with sampling day. Although there was little change in fatty acid compositions within each treatment over time, the fatty acid profiles differed in several aspects among the 3 treatments (Table 1). Most notably, the percentage of 20:4(n-6) was highest in meronts from the lipid-free medium treatment (19 to $22 \%$ ) (Table 1), followed by meronts in regular medium (14 to $17 \%$ ), and was lowest in the YRW treatment ( 6 to $7 \%$ ). The percentage of $n-3$ polyunsaturated fatty acids (PUFAs) was much lower in the lipid-free medium treatment ( 0.8 to $09 \%$ or $<0.2 \%$ ) than in the regular medium and YRW treatments (both 3.2 to $4.5 \%$ ). The surviving meronts in YRW maintained a relatively similar weight \% fatty acid profile as those at Day 0 (initial). The fatty acid 18:1(n-9), precursor of 20:4(n-6), was abundant in all treatments. However, only meronts in YRW maintained consistently levels of this fatty acid similar to the initial (34 to $35 \%$ ) over time.

Individual fatty acid content in cultures

The masses $(\mu \mathrm{g})$ of all major fatty acids differed significantly $(\mathrm{p}<0.05)$ between treatments, but 16:0, 16:1 $(n-7), 18: 0,18: 1(n-7), 18: 2(n-6)$ and 22:1(n-9) did not vary significantly with sampling day (Table 2 ). Individual fatty acid contents in meronts maintained in regular and lipid-free media increased as the meront cell number increased compared to initial values, while those maintained in YRW decreased over time due to declining cell numbers (Table 2). The increase in 16:0, 18:0, 18:1(n-9) and 20:4(n-6) was particularly obvious in meronts cultured in regular medium. Similarly, total saturated, mono-unsaturated, n-3 and n-6 fatty acids and total fatty acids increased with increasing meront number in regular and lipid-free media, whereas all in YRW decreased. However, the increase in the culture in lipid-free medium began to level off after Day 7.

\section{Expt 2A. Infectivity of meronts in host-free environment}

All treatment groups except the negative controls contained oysters with Perkinsus marinus infection (Table 3, Fig. 5). Prevalence of infection ranged from 80 to $100 \%$ and no infection was detected in negative controls. The oysters inoculated with meronts previously maintained in ASW for $7 \mathrm{~d}$ had the highest infection prevalence $(100 \%)$. The oysters inoculated with viable meront cells that had just been transferred to ASW had significantly lower prevalence ( $p<0.05$ ) than those inoculated with viable $7 \mathrm{~d}$ ASW-incubated meronts. All infections in oysters were light. Average infection intensities were $59 \pm 83,299 \pm 512$ and $5767 \pm$ 1190 cells $\mathrm{g}^{-1}$ wet tissue in oysters inoculated with meronts kept in ASW for 0, 2 and $7 \mathrm{~d}$, respectively.

\section{Expt 2B. Infectivity of meronts in host-free environment}

Results were similar to those of Expt 2A, with $100 \%$ infection prevalence in oysters inoculated with meronts that had been kept in ASW for 7 d, while significantly ( $p$ 
Table 2. Perkinsus marinus. Fatty acid content ( $\mu \mathrm{g}$, mean $\pm \mathrm{SD}, \mathrm{n}=3$ ) of meront cells in cultures (10 ml) maintained in regular medium, lipid-free medium and filtered York River water for $14 \mathrm{~d}$ (Expt 1B). Only fatty acids comprising $>2 \%$ of total fatty acids are shown. Sat: total saturated fatty acids; Mono: total mono-unsaturated fatty acids; n-3: total n-3 unsaturated fatty acids; n-6: total n-6 unsaturated fatty acids; Total: total fatty acids; other abbreviations as in Table 1. 'a: Significantly different for 'treatment' $(p<0.05){ }^{b}$ : significantly different for 'day' $(p<0.05)$

\begin{tabular}{|c|c|c|c|c|c|c|c|c|c|c|}
\hline \multirow[t]{2}{*}{ FAME } & \multirow{2}{*}{$\begin{array}{c}\text { Day } 0 \\
\text { (initial) }\end{array}$} & \multicolumn{3}{|c|}{ Day 3} & \multicolumn{3}{|c|}{ Day 7} & \multicolumn{3}{|c|}{ - Day 14} \\
\hline & & $\mathrm{RM}$ & LF & YRW & $\mathrm{RM}$ & LF & YRW & $\mathrm{RM}$ & LF & YRW \\
\hline $14: 0^{\mathrm{ab}}$ & 3.4 & $12.4 \pm 0.9$ & $6.8 \pm 0.8$ & $1.7 \pm 0.4$ & $12.4 \pm 0.6$ & $6.0 \pm 0.5$ & $1.5 \pm 0.1$ & $11.2 \pm 0.4$ & $3.8 \pm 0.5$ & $0.9 \pm 0.3$ \\
\hline $16: 0^{a}$ & 5.7 & $28.7 \pm 2.0$ & $18.6 \pm 1.8$ & $3.0 \pm 0.7$ & $32.1 \pm 0.9$ & $18.9 \pm 1.1$ & $2.5 \pm 0.1$ & $35.3 \pm 1.5$ & $17.1 \pm 2.3$ & $2.4 \pm 0.3$ \\
\hline $16: 1(n-7)^{a}$ & 1.7 & $4.5 \pm 0.3$ & $1.6 \pm 0.1$ & $0.8 \pm 0.2$ & $3.8 \pm 0.1$ & $1.6 \pm 0.1$ & $0.7 \pm 0.0$ & $3.6 \pm 0.1$ & $1.3 \pm 0.2$ & $0.6 \pm 0.0$ \\
\hline $18: 0^{a}$ & 3.4 & $14.8 \pm 1.5$ & $10.8 \pm 1.0$ & $1.3 \pm 0.3$ & $21.9 \pm 0.3$ & $10.4 \pm 0.5$ & $1.0 \pm 0.0$ & $18.9 \pm 1.2$ & $6.8 \pm 0.6$ & $1.0 \pm 0.2$ \\
\hline $18: 1(n-9)^{a b}$ & 17.5 & $49.3 \pm 3.5$ & $38.1 \pm 3.3$ & $7.3 \pm 1.7$ & $80.0 \pm 2.3$ & $66.0 \pm 3.4$ & $6.4 \pm 0.1$ & $96.9 \pm 4.0$ & $64.9 \pm 7.8$ & $6.4 \pm 0.3$ \\
\hline $18: 1(n-7)^{a}$ & 2.4 & $6.0 \pm 0.4$ & $2.5 \pm 0.2$ & $0.9 \pm 0.2$ & $5.9 \pm 0.1$ & $2.5 \pm 0.1$ & $0.8 \pm 0.0$ & $5.9 \pm 0.3$ & $2.1 \pm 0.3$ & $0.8 \pm 0.0$ \\
\hline $18: 2(\mathrm{n}-6)^{\mathrm{a}}$ & 1.4 & $8.9 \pm 0.5$ & $7.7 \pm 0.5$ & $0.7 \pm 0.2$ & $8.1 \pm 0.2$ & $8.2 \pm 0.4$ & $0.6 \pm 0.0$ & $9.3 \pm 0.3$ & $7.8 \pm 0.9$ & $0.6 \pm 0.0$ \\
\hline $20: 1(n-9)^{a b}$ & 5.0 & $12.0 \pm 0.8$ & $9.4 \pm 0.8$ & $1.6 \pm 0.4$ & $20.7 \pm 0.3$ & $15.5 \pm 0.5$ & $1.2 \pm 0.0$ & $18.8 \pm 1.5$ & $10.3 \pm 0.7$ & $1.3 \pm 0.1$ \\
\hline $20: 4(n-6)^{a b}$ & 3.4 & $36.3 \pm 1.0$ & $33.8 \pm 4.0$ & $1.3 \pm 0.3$ & $40.0 \pm 0.4$ & $40.7 \pm 2.1$ & $1.1 \pm 0.0$ & $46.1 \pm 2.8$ & $41.5 \pm 4.2$ & $1.3 \pm 0.1$ \\
\hline $20: 5(n-3)^{a b}$ & 1.7 & $6.0 \pm 0.1$ & $1.5 \pm 0.2$ & $0.6 \pm 0.1$ & $6.7 \pm 0.2$ & $1.7 \pm 0.1$ & $0.6 \pm 0.0$ & $7.9 \pm 0.2$ & $1.7 \pm 0.2$ & $0.6 \pm 0.1$ \\
\hline $22: 1(n-9)^{a}$ & 1.1 & $1.6 \pm 0.2$ & Trace & Trace & $2.4 \pm 0.3$ & Trace & Trace & $1.6 \pm 0.1$ & Trace & $0.2 \pm 0.0$ \\
\hline $24: 0^{\mathrm{ab}}$ & 1.3 & $11.0 \pm 0.2$ & $9.2 \pm 0.4$ & $0.5 \pm 0.1$ & $14.0 \pm 0.6$ & $12.6 \pm 0.4$ & $0.6 \pm 0.0$ & $15.3 \pm 0.9$ & $11.7 \pm 0.6$ & $0.6 \pm 0.0$ \\
\hline Sat ${ }^{a b}$ & 15.24 & $73.0 \pm 5.0$ & $50.7 \pm 4.3$ & $6.8 \pm 1.4$ & $93.9 \pm 1.2$ & $55.8 \pm 2.8$ & $5.8 \pm 0.2$ & $94.0 \pm 4.7$ & $46.4 \pm 4.5$ & $5.5 \pm 0.8$ \\
\hline Mono $^{\mathrm{ab}}$ & 29.05 & $80.1 \pm 6.1$ & $56.1 \pm 4.9$ & $11.2 \pm 2.6$ & $120.2 \pm 2.5$ & $91.7 \pm 4.4$ & $9.6 \pm 0.3$ & $135.2 \pm 6.4$ & $84.1 \pm 9.1$ & $9.7 \pm 0.5$ \\
\hline$n-3^{a b}$ & 2.51 & $9.9 \pm 0.2$ & $1.5 \pm 0.2$ & $0.9 \pm 0.1$ & $10.8 \pm 0.1$ & $1.7 \pm 0.1$ & $0.8 \pm 0.0$ & $11.4 \pm 0.4$ & $1.7 \pm 0.2$ & $0.9 \pm 0.1$ \\
\hline$n-6^{a b}$ & 4.80 & $51.0 \pm 1.7$ & $46.2 \pm 4.9$ & $2.0 \pm 0.4$ & $54.5 \pm 0.7$ & $54.2 \pm 2.8$ & $1.8 \pm 0.0$ & $62.1 \pm 3.6$ & $53.4 \pm 5.2$ & $1.9 \pm 0.1$ \\
\hline Total $^{\text {ab }}$ & $52.2 \quad 2$ & $216.0 \pm 13.2$ & $156.5 \pm 13.6$ & $21.4 \pm 4.6$ & $283.3 \pm 3.8$ & $206.9 \pm 10.2$ & $18.2 \pm 0.4$ & $306.5 \pm 15.3$ & $188.2 \pm 19.4$ & $18.4 \pm 1.0$ \\
\hline
\end{tabular}

$<0.05)$ fewer oysters were infected in the group injected with meronts that had not been kept in ASW and in the treatment injected with meronts that had been in ASW for $3 \mathrm{~d}$, (62 and 48\%, respectively) (Fig. 6). However, unlike Expt 2A, 1 oyster was detected with 3 Perkinsus marinus cells $\mathrm{g}^{-1}$ wet tissue in the negative control (Fig. 6). Average infection intensities were $23 \pm$ $35,15 \pm 18$ and $316 \pm 560$ cells g ${ }^{-1}$ wet tissue weight in the treatments inoculated with meronts kept in ASW for 0,3 and $7 \mathrm{~d}$, respectively (Table 3 ).

Low mortality was noted in both Expts $2 \mathrm{~A}$ and B: 1 oyster was found dead in the treatment group in-

Table 3. Crassostrea virginica infected by Perkinsus marinus. Parasite density (mean $\pm \mathrm{SD} \mathrm{n}=21$ oysters in each incubation period) in oysters experimentally infected with viable $P$. marinus meront cells incubated in artificial seawater (ASW) for 0, 2 or $7 \mathrm{~d}$ (Expt 2A) and for 0, 3 or $7 \mathrm{~d}$ (Expt 2B). Average intensities calculated for infected oysters only. No $P$. marinus infection was detected in any oyster in the control group in Expt $2 \mathrm{~A}_{;} 1$ oyster in control treatment was infected with 3 cells $\mathrm{g}^{-1}$ wet tissue wt in Expt 2B

\begin{tabular}{|c|c|c|c|c|}
\hline & \multicolumn{4}{|c|}{ Days incubated in ASW } \\
\hline & $\begin{array}{c}\text { Day } 0 \\
\text { (initial) }\end{array}$ & $2 \mathrm{~d}$ & $3 \mathrm{~d}$ & $7 \mathrm{~d}$ \\
\hline \multicolumn{5}{|c|}{ Mean density (cells $\mathrm{g}^{-1}$ wet tissue wt) } \\
\hline Expt 2A & $59 \pm 83$ & \multirow{2}{*}{$299 \pm 512$} & & $767 \pm 1190$ \\
\hline Expt 2B & $23 \pm 35$ & & $15 \pm 18$ & $316 \pm 560$ \\
\hline \multicolumn{5}{|l|}{ Range } \\
\hline Expt 2A & $2-278$ & \multirow[t]{2}{*}{$3-1770$} & & $8-3795$ \\
\hline Expt 2B & $3-110$ & & $3-63$ & $4-1864$ \\
\hline
\end{tabular}

oculated with meronts incubated in ASW for $2 \mathrm{~d}$ in Expt 2A, and 1 death occurred in the treatment injected with meronts incubated in ASW for $7 \mathrm{~d}$ in Expt 2B.

\section{DISCUSSION}

Perkinsus marinus is transmitted between oysters via water-borne infective cells (Ray 1954, Mackin 1962, Andrews 1988, Volety \& Chu 1994, Ragone Calvo et al. 2003). While cells released from degraded tissues of infected dead oysters are the primary source of infective cells for $P$. marinus transmission (Mackin 1962, Andrews 1988, Ragone Calvo et al. 2003), dispersion of infective cells via feces and pseudo-feces may also be sources of infective particles (Bushek et al. 2002). Infective cells released from a host during summer (the period during which disease prevalence and intensity peak) are believed to be able to survive in the water column through the winter and are infective when they enter a new host in the following spring (Mackin 1962). Our study is the first to investigate how long the primary transmission stage, meront, remains viable in the water column and whether or not the 'viable' meronts are infective. Our results show that viable meronts remained infective in ASW at least for $7 \mathrm{~d}$. Meronts kept in lipid-free medium for $14 \mathrm{~d}$ 


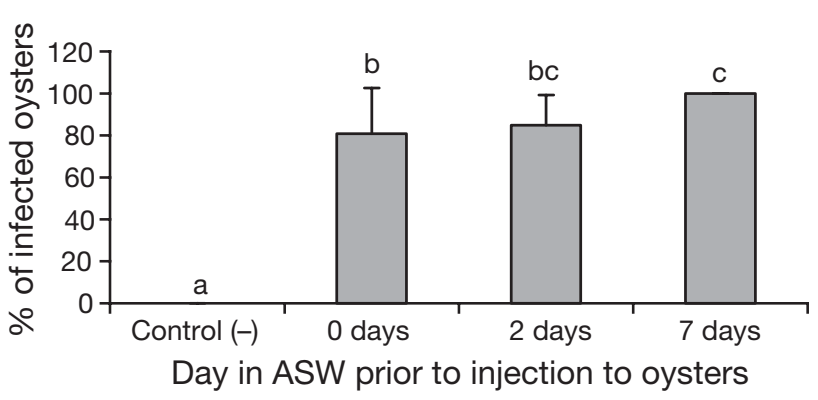

Fig. 5. Crassostrea virginica infected by Perkinsus marinus. $P$. marinus prevalence (\% infected oysters, Mean $\pm \mathrm{SD}$, Expt 2A) in oysters inoculated with $100 \mu \mathrm{l}$ of artificial seawater (ASW) containing $1.5 \times 10^{6}$ viable $P$. marinus cells that had been incubated in ASW for 0, 2 or $7 \mathrm{~d}$ ( $\mathrm{n}=21$ oysters per incubation period). Control (-): negative control, oysters inoculated with $100 \mu \mathrm{l}$ ASW. Different letters denote significant differences between treatments $(p<0.05)$

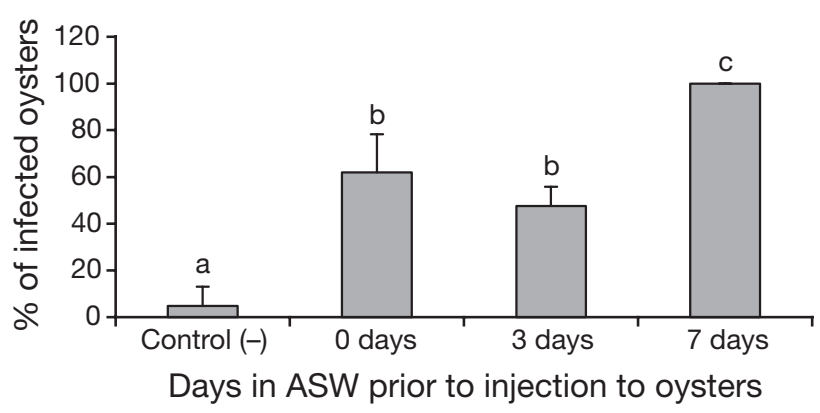

Fig. 6. Crassostrea virginica infected by Perkinsus marinus. $P$. marinus prevalence (\% infected oysters, Mean $\pm \mathrm{SD}$, Expt $2 \mathrm{~B}$ ) in oysters inoculated with $100 \mu \mathrm{l}$ ASW containing $4.0 \times 10^{6}$ viable $P$. marinus cells that had been incubated in ASW for 0,3 or $7 \mathrm{~d}(\mathrm{n}=21$ oysters per incubation period). Further details as in Fig. 5

retained their ability to synthesize fatty acids, including arachidonic acid [20:4(n-6)]. The fatty acid synthetic ability of meronts in lipid-free medium may be related to disease transmission processes.

In addition to temperature and salinity, the in situ concentration of Perkinsus marinus meronts is critical for disease transmission and development (Volety \& Chu 1994, Chu 1996, Chu \& Volety 1997, Ragone Calvo et al. 2003). Dose-dependent transmission of various $P$. marinus life stages has been demonstrated in laboratory experiments (Volety \& Chu 1994). In a study investigating $P$. marinus transmission in oysters in relation to water temperature, oyster mortality and water column abundance of anti- $P$. marinus antibody-labeled cells enumerated by flow cytometry, it was noted that peak $P$. marinus infection acquisition coincided with elevated abundance of water-borne $P$. marinus cells and was highest at the time of maximum cell abundance (Ragone Calvo et al. 2003). However, a significant relationship between cell abundance and infection-acqui- sition rate was not observed. Ragone Calvo et al. (2003) speculated that the insignificant correlation between cell abundance and infection incidence was because (1) the enumerated cells were not equally infective and/or (2) through cross-reaction of anti-P. marinus antibody with other microbes. It is also possible that not all the enumerated cells were viable, since the viability of the immuno-stained cells was not determined. Our results revealed heavy mortality in meronts as soon as they were transferred to YRW. Viability was reduced from an initial value of nearly 100 to $7.8 \%$ at Day 3 and $6.1 \%$ at Day 14. However, those meronts that did survive the initial high mortality were still viable after $14 \mathrm{~d}$. Also, although some mortality occurred in meronts maintained in lipid-free medium, the surviving viable meronts were capable of replicating (Figs. $1 \& 3$ ), and survived for a relatively long time (24 d, Fig. 3).

In the present study, oysters were experimentally infected with similar doses of surviving/viable meronts. Apparently viable Perkinsus marinus meronts are infective for at least $7 \mathrm{~d}$ in ASW outside the host. Higher $P$. marinus infection prevalence $(100 \%)$ in the treatment inoculated with meronts that had been kept in ASW for $7 \mathrm{~d}$ is particularly interesting, although difficult to interpret. One possible explanation is that it takes time for the parasites from one environment (culture medium) to adjust to a new environment (ASW). The initial high mortality in meronts kept in YRW and in meronts maintained in lipid-free medium supports this. If it is assumed that the culture medium environment is a simulation of the host condition, then one would expect that heavy mortality would occur when meronts become host-disassociated, i.e. released to the water column via decaying of dead infected oyster tissues and/or feces and pseudo-feces. Possibly, those surviving can remain viable in the water column (i.e. ASW in the present study) for a long time and have 'physiologically adapted' to the new environment.

In the present study, infectivity was tested in meronts held in ASW up to only $7 \mathrm{~d}$. We believe that infectivity of meronts in nature may well persist beyond $7 \mathrm{~d}$. In the present study, after initial mortality, meronts in lipid-free medium and YRW survived for up to 24 and $14 \mathrm{~d}$, respectively (Fig. 2). As indicated in the 'Introduction', although potential transmission vectors and reservoirs for Perkinsus marinus have been proposed (Andrew \& Hewatt 1957, Hoese 1963, White et al. 1987), no secondary host has been reported and its host is a benthic sedentary bivalve Crassostrea virginica. Thus, $P$. marinus infective cells such as meronts probably rely mainly on water and tidal currents to reach distant host populations. Increased survival time may result in enhanced dispersal distance of infective cells. 
That only light infection (Table 3) was noted in oysters in all treatment groups after 9 wk of meront injection is not surprising since cultured meront cells are usually less infective or virulent than wild meront cells isolated from infected oysters (Bushek et al. 1994a, Chintala et al. 2002, Ford et al. 2002). The single infection in the control group probably originated from Maine.

Fatty acid synthetic activity continued, with a slight increase in 18:1(1n-9) and 20:4(n-6) in meronts maintained in lipid-free medium. The decrease of fatty acid content in those meronts maintained in YRW was due to heavy mortality, which resulted in reduction in cell numbers. This suggests that the nutrients in YRW cannot sustain fatty acids and lipid synthesis, thus prohibiting proliferation, although the survivors managed to maintain a fatty acid profile similar to that of the inoculum. The lipid-free medium consists of many small components such as amino acids, vitamins and sugars. In nature, there is dissolved organic matter (DOM) comprised of similar molecules including free amino acids, monosaccharides and short chain, free fatty acids. Although most of these are refractory, there is considerable evidence that many microbes, filter feeders and larval and juvenile fishes consume them for energy, particularly at times of food limitation (Manahan 1983, Feral 1985, Korsgaard 1991, Diaz et al. 1994, Otake et al. 1995, Kragh \& Sondergaard 2004). The infectivity shown by meronts maintained in ASW for $7 \mathrm{~d}$ was surprising, since ASW contains only inorganic salts. With this in mind, it is conceivable that meront cells can live in the water column for days, if not weeks, until an opportunity for reinfection arises. Hyponospores of Perkinsus marinus can tolerate temperatures as low as $4^{\circ} \mathrm{C}$ for 4 to $7 \mathrm{~d}$ (Chu \& Greene 1989), and within oyster tissues hyponospores remained viable after freezing (Andrew \& Hewatt 1957). Thus, the suggestion that $P$. marinus may survive over the winter outside its host and reinfect oysters the following spring (Mackin 1962) is supportable. However, a time frame of several months outside the host may be too long a period for the parasite to survive without the essential nutrient supply derived from the host environment, especially since DOM availability and concentration are seasonally variable. We found high cell mortality in $P$. marinus meront cell culture at the stationary phase in regular media. Cell viability dropped below $40 \%$ in 28 d old cultures and ranged from 11 to $25 \%$ between 38 and 47 d old cultures (Soudant et al. 2005). Thus, in addition to low temperature and salinity, nutrient availability could be a limiting factor for $P$. marinus distribution.

The heavy mortality in Perkinsus marinus at the stationary phase and beyond may be due to limitation of sterols. Sterols are essential structural components in addition to phospholipids and long chain polyunsatu- rated fatty acids. Thus far, only parasitic protozoans of the family Trypanosomatidae have been reported to have the ability of synthesizing sterols (Contreras et al. 1997, Lepesheva et al. 2004). Although P. marinus has a greater fatty acid synthetic ability than other parasitic protozoans (Chu et al. 2002), it must acquire sterols from its host for survival and membrane synthesis. We have found that meronts proliferate in medium with cholesterol as the only lipid source (unpubl. obs.). $P$. marinus meronts are also incapable of synthesizing n-3 fatty acids (Soudant \& Chu 2001, Chu et al. 2002). The increase in n-3 long chain fatty acids such as 20:5(n-3) and 22:6(n-3) in meronts grown in regular medium is due to incorporation and assimilation rather than de novo synthesis.

In summary, the present study has demonstrated that although heavy mortality occurred when in vitro cultured meronts were transferred to estuarine water (i.e. YRW), the survivors remained viable for up to $14 \mathrm{~d}$. Despite some mortality in meronts maintained in lipidfree medium, those that survived were able to replicate and their fatty acid synthetic ability continued. Viable meronts that had been kept in ASW for 2, 3 or $7 \mathrm{~d}$ were infective. The highest Perkinsus marinus prevalence $(100 \%)$ was in the oysters inoculated with meronts that had been kept in ASW for $7 \mathrm{~d}$. These results suggest that $P$. marinus meront cells can survive for at least $14 \mathrm{~d}$ in the water column and that viable meronts remain infective for at least $7 \mathrm{~d}$. However, the present study was conducted using in vitro cultured meront cells, which could differ greatly from wild meronts in terms of survival and infectivity. Future studies should be directed at testing the viability and infectivity of wild meronts freshly isolated from infected oyster tissues, and should extend the length of incubation time in water for longer than $7 \mathrm{~d}$.

Acknowledgements. This study was supported by a grant from the Metabolic Biochemistry Program, Molecular and Cellular Bioscience Division, National Science Foundation (MCB-0131108). The authors thank G. Constantin and V. Encomio for technical assistance. The authors are grateful for J. Cope's assistance in statistical analysis. Contribution number 2705 from the Virginia Institute of Marine Science, College of William and Mary, USA.

\section{LITERATURE CITED}

Andrew JD, Hewatt WG (1957) Oyster mortality studies in Virginia. II. The fungus disease caused by Dermocystidium martinum in oysters of Chesapeake Bay. Ecol Monogr 27:1-26

Andrews JD (1988) Epizootiology of the disease caused by the oyster pathogen Perkinsus marinus and its effects on the oyster industry. Am Fish Soc Spec Publ 18:47-63

Bligh EG, Dyer WJ (1959) A rapid method of total lipid extraction and purification. Can J Biochem Physiol 37:911-917 
Bushek D, Allen SK Jr, Alcox KA, Gustafson R, Ford SE (1994a) Dose response of the eastern oyster, Crassostrea virginica, to cultured cells of Perkinsus marinus, the agent of dermo disease. J Shellfish Res 13:313

Bushek D, Ford SE, Allen SK Jr (1994b) Evaluation of methods using Ray's fluid thioglycollate medium for diagnosis of Perkinsus marinus infection in the eastern oyster, Crassostrea virginica. Annu Rev Fish Dis 4:201-217

Bushek D, Ford SE, Chintala MM (2002) Comparison of in vitro-cultured and wild-type Perkinsus marinus. III. Fecal elimination and its role in transmission. Dis Aquat Org 51: 217-225

Chintala MM, Bushek D, Ford SE (2002) Comparison of in vitro-cultured and wild-type Perkinsus marinus. II. Dosing methods and host response Dis Aquat Org 51:203-216

Choi KS, Wilson EA, Lewis DH, Powell EN, Ray SM (1989) The energetic cost of Perkinsus marinus parasitism in oysters: quantification of the thioglycollate method. J Shellfish Res 8:125-131

Chu FLE (1996) Laboratory investigations of susceptibility, infectivity and transmission of Perkinsus marinus in oysters. J Shellfish Res 15:57-66

Chu FLE, Greene KH (1989) Effect of temperature and salinity on in vitro culture of the oyster pathogen, Perkinsus marinus (Apicomplexa: Perkinsea). J Invertebr Pathol 53:260-268

Chu FLE, Volety A (1997) Disease processes of the parasite Perkinsus marinus in eastern oyster Crassostrea virginica: minimum dose for infection initiation, and interaction of temperature, salinity and infective cell dose. Dis Aquat Org 28:61-68

Chu FLE, Lund ED, Soudant P, Harvey E (2002) De novo arachidonic acid synthesis in Perkinsus marinus, a protozoan parasite of the eastern oyster Crassostrea virginica. Mol Biochem Parasitol 119:179-90

Chu FLE, Lund ED, Harvey E, Adlof R (2004) Arachidonic acid synthetic pathway of the oyster protozoan parasite, Perkinsus marinus: evidence for usage of a delta-8 pathway. Mol Biochem Parasitol 133:45-51

Contreras LM, Vivas J, Urbina JA (1997) Altered lipid composition and enzyme activities of plasma membranes from Trypanosoma (Schizotrypanum) cruzi epimastigotes grown in the presence of sterol biosynthesis inhibitors. Biochem Pharmacol 53:697-704

Diaz JP, Mani-Ponset L, Guyot E, Connes R (1994) Assimilation of dissolved glucose from sea water by the sea bass Dicentrarchus labrax and the sea bream Sparus aurata. Mar Biol 120:181-186

Feral JP (1985) Effect of short-term starvation on the biochemical composition of the apodus holothurian Leptosynapta galliennei (Echinodermata): possible role of dissolved organic matter as an energy source. Mar Biol 86: 297-306

Ford SE (1996) Range extension by the oyster parasite Perkinsus marinus into the northeastern United States: response to climate change? J Shellfish Res 15:45-56

Ford SE, Chintala MM, Bushek D (2002) Comparison of in vitro-cultured and wild-type Perkinsus marinus. I. Pathogen virulence. Dis Aquat Org 51:187-201

Hoese HD (1963) Studies on oyster scavengers and their relation to the fungus Dermocystidium marinum. Proc Natl Shellfish Assoc 53:161-174

Korsgaard B (1991) Metabolism of larval turbot Scophthalmus maximus (L.) and uptake of amino acids from seawater studied by autoradiographic and radiochemical methods.

Editorial responsibility: Albert K. Sparks,

Seattle, Washington, USA
J Exp Mar Biol Ecol 148:1-10

Kragh T, Sondergaard M (2004) Production and bioavailability of auchthonous dissolved organic carbon: effects of mesozooplankton. Aquat Microb Ecol 36:61-72

La Peyre JF, Chu FLE (1994) A simple procedure for the isolation of Perkinsus marinus merozoites, a pathogen of the eastern oyster, Crassostrea virginica. Bull Eur Assoc Fish Pathol 14:101-103

La Peyre JF, Faisal M, Burreson EM (1993) In vitro propagation of the protozoan Perkinsus marinus, a pathogen of the eastern oyster, Crassostrea virginica. J Eukaryot Microbiol 40:304-310

Lepesheva GI, Nes WD, Zhou W, Hill GC, Waterman MR (2004) CYP51 from Trypanosoma brucei is obtusifoliolspecific. Biochemistry 43:10789-10799

Lund ED, Chu FLE, Harvey E (2004) Effects of temperature and salinity on fatty acid synthesis in the oyster protozoan parasite Perkinsus marinus. J Exp Mar Biol Ecol 307: $111-126$

Mackin JG (1962) Oyster disease caused by Dermocystidium marinum and other microorganisms in Louisiana. Publ Inst Mar Sci Univ Tex 7:132-229

Manahan DT (1983) The uptake and metabolism of dissolved amino acids by bivalve larvae. Biol Bull (Woods Hole) 164: $236-250$

Marty Y, Delaunay F, Moal J, Samain JF (1992) Change in the fatty acid composition of Pecten maximus (L.). J Exp Mar Biol Ecol 163:221-234

Metcalfe LD, Schmitz AA (1961) The rapid preparation of fatty acid esters for gas chromatography analysis. Anal Chem 33:363-364

Otake T, Hirokawa J, Fujimoto H, Imaizumi K (1995) Fine structure and function of the gut epithelium of pike eel larvae. J Fish Biol 47:126-142

Perkins FO (1966) Life history studies of Dermocystidium marinum, an oyster pathogen. PhD dissertation, Florida State University, Tallahassee, FL

Perkins FO (1988) Structure of protistan parasites found in bivalve molluscs. Am Fish Soc Spec Publ 18:93-111

Ragone Calvo LM, Dungan CF, Roberson BS, Burreson EM (2003) Systematic evaluation of factors controlling Perkinsus marinus transmission dynamics in lower Chesapeake Bay. Dis Aquat Org 56:75-86

Ray SM (1954) Biological studies of Dermocystidium marinum, a fungus parasite of oysters. Rice Institute Pamphlet Special. The Rice Institute, Houston, TX

Soudant P, Chu FLE (2001) Lipid class and fatty acid composition of the protozoan parasite of oysters, Perkinsus marinus, cultivated in two different media. J Eukaryot Microbiol 48:309-319

Soudant P, Chu FLE, Lund ED (2005) Assessment of the cell viability of cultured Perkinsus marinus (Perkinsea), a parasitic protozoan of the eastern oyster, Crassostrea virginica, using SYBRgreen-propidium iodide double staining and flow cytometry. J Eukaryot Microbiol 52: 492-499

Volety AK, Chu FLE (1994) Comparison of infectivity and pathogenicity of meront (trophozoite) and prezoosporangia stages of the oyster pathogen Perkinsus marinus in eastern oysters, Crassostrea virginica (Gmelin, 1791). J Shellfish Res 13:521-527

White ME, Powell EN, Ray SM, Wilson EA (1987) Host-to-host transmission of Perkinsus marinus in oyster Crassostrea virginica populations by the ectoparasitic snail Boonea impressa (Pyramidellidae). J Shellfish Res 6:1-5

Submitted: August 13, 2005; Accepted: March 1, 2006

Proofs received from author(s): July 18, 2006 